\title{
Regeneration and Genetic Transformation by pAB6 Plasmid of Hyoscyamus muticus L., (Egyptian Henbane) Using Particle Bombardment El-Akkad, T. A. ${ }^{1}$; A. M. Serag ${ }^{1}$ and Wessam Serag ${ }^{2}$ \\ ${ }^{1}$ Department of Genetics and Genetic Engineering, Faculty of Agriculture, Benha University, Egypt \\ ${ }^{2}$ Tissue Culture and Germplasm Conservation Lab., Hort. Res. Inst., Agric. Res. Centre, Egypt
}

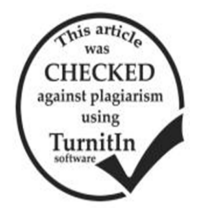

\section{ABSTRACT}

Media chemical composition effect on production of embryogenic calli and production of transformed plants from Hyoscyamus muticus L (Egyptian henbane) were assessed using gene gun. Hyoscyamus muticus L., (Egyptian Henbane) is medically and economically important plant as it contains widely used atropine alkaloids, scopolamine, hyoscyamine. Callus induction and regeneration ability from leaf of Hyoscyamus muticus L were examined. Effects of 7 media were evaluated on type II callus production and regeneration. T3 medium showed greater positive response in embryogenic calli formation frequency (84.95\%), reflected on shoot formation frequency (7.65/explant) and produced a high root yields after transfer on the rooting medium. Transformed henbane plants were achieved by particle bombardment using plasmid pAB-6 harboring the gus and bar genes with transformation efficiency $13.4 \%$. Total alkaloid contents were reached to $6.05 \%$ in transformed plants. It compared with untransformed plants which contained $2.95 \%$. Keywords: Hyoscyamus muticus L, regeneration, genetic transformation, particle bombardment.

\section{INTRODUCTION}

High interests in plant research concerning potentials of medicinal use has been progressively increased during the last decade.

The WHO (1999) stated that medicinal plants are used as medical herbs, pharmaceuticals, cosmetics and other uses and around fifteen thousand species representing one tenth of all species are used in medical purposes. Among substances and materials found in medicinal plants there are anticancer compounds, antibiotics, and others (Hai-Hang., 2012).

Hyoscyamus muticus L., commonly known as Egyptian henbane (Family Solanaceae), is a winter crop which is medicinally and economically important as it contains widely used tropane alkaloids, scopolamine, hyoscyamine and atropine. The crude drug contains hyoscyamine, hyoscyine (scopolamine) and atropine, is used in against nervous disorders, asthma and whooping cough. Scopolamine and atropine (a racemic mixture of Lhyoscyamine) are used in ophthalmology and in combination as analgesics or narcotics; the former is used in controlling motion sickness (Berlin., 1988). Anthocyanin, which is a biologically and economically important natural pigment, which is found in the plant and also in its in vitro grown callus cultures (Bekheet et al., 2013).

In vitro regeneration and genetic transformations are used to multiply and enhance and produce medicinal plants and their metabolites (Abd El-Motaleb, et al., 2015)

Particle bombardment has been widely used to transform exogenous genes into plant tissues and has a major impact on basic plant biotechnology (Ahmad et al., 2017). Purkayastha et al., (2010) stated that transforming Hyoscyamus muticus L. through genetic means is not effective in comparison with the use of medical plants.

The present investigation was aimed at (1) attaining an effective regeneration Hyoscyamus muticus L. (2) assessing the most effective of composition of media composition for callus formation taking in consideration contents of alkaloids (hyoscyamines) (3) Transforming Hyoscyamus muticus L. calli systems with plasmid-DNA having Gus gene and herbicide resistant bar gene as a marker (4) confirming gene integration in the putatively transformed plants using PCR.

\section{MATERIALS AND METHODS}

Plant Genotype of plant and preparation of media

Seeds of Hyoscyamus muticus L were obtained from Gene bank, Desert Research Center, Egypt. Seeds were immersed for $10 \mathrm{~min}$ into $0.1 \%$ mercuric chloride solution, then rinsed 4 times with d.w. ; then left to germinate in jars containing $10 \mathrm{~mL}$ MS (half-strength) (Murashige and Skoog, 1962) supplemented with myoinositol $\left(100 \quad \mathrm{mgL}^{-1}\right)$, thiamine- $\mathrm{HCl} \quad\left(2 \quad \mathrm{mgL}^{-1}\right)$ pyridoxine- $\mathrm{HCl}\left(0.5 \mathrm{mgL}^{-1}\right)$ nicotinic acid $\left(0.5 \mathrm{mgL}^{-1}\right)$ and sucrose $\left(30 \mathrm{~g} \mathrm{~L}^{-1}\right)$.

Media solidification was done using $3 \mathrm{~g}_{\text {agar } \mathrm{L}^{-1}}$ agar and cultures were left for 2 days in dark under temperature of $18 \pm 1^{\circ} \mathrm{C}$ then in light for $16 \mathrm{~h}$ with $50 \mu \mathrm{mol}$ $\mathrm{m}^{-2} \mathrm{~s}^{-1}\left(25^{\circ} \mathrm{C}\right)$ and $8 \mathrm{~h}$ dark $\left(20^{\circ} \mathrm{C}\right)$.

\section{Callus induction and regeneration}

Leaves were shredded in pieces and transferred to the callus induction media to obtain a sufficient number of in vitro embryogenic callus as shown in Table 1, then left in dark $\left(25^{\circ} \mathrm{C}\right)$ for 2 months and sub-cultured for two weeks onto fresh medium of same composition. Selection was done by discarding the slow growing and dark calli during the next subcultures. The number of embryogenic calli was calculated 8 weeks kater and pieces were transferred to regeneration media.

All calli initiated on different callus induction media were moved to a medium containing $2.0 \mathrm{mg} \mathrm{L}^{-1} \mathrm{kin}$ for shoot development. Callus cultures were incubated for 4 weeks at $25^{\circ} \mathrm{C}$ with 8 to $16 \mathrm{~h}$ photoperiod from coolwhite fluorescent lights with an intensity of 2000 lux. Germinated embryoids having small and large shoots were moved to a rooting medium (MS+ $\left.4.0 \mathrm{mg} \mathrm{L}^{-1} \mathrm{IBA}\right)$. Shoots developed into plantlets which were transferred to an aquarium having modified Hoagland solution (Johnson et al., 1957).

Healthy plantlets taken from the nutrient solution and put into pots of peat moss: soil: sand mixture (1:1:1 by volume) in a greenhouse under ambient temperature of 22 to $25{ }^{\circ} \mathrm{C}, 16 \mathrm{~h}$ photoperiod and $50 \%$ humidity. Pots were watered with half strength Hoagland solution.

Total alkaloids (Hyoscyamine Alkaloids) were determined spectrophotometry according to methods of Ganga et al. (2011). 
Table 1. Components of media used for callus induction, regeneration and rooting of Hyoscyamus muticus $\mathrm{L}$.

\begin{tabular}{|c|c|c|c|}
\hline Medium number & $\begin{array}{c}\text { Callus induction } \\
\text { medium }\end{array}$ & $\begin{array}{l}\text { Shoot induction } \\
\text { medium }\end{array}$ & $\begin{array}{l}\text { Rooting } \\
\text { medium }\end{array}$ \\
\hline $\mathrm{T} 1$ & $\begin{array}{c}\mathrm{MS}+0.5 \mathrm{mg} / \mathrm{L} \mathrm{kin} \text { (kinten)+ } 1 \mathrm{mg} / \mathrm{L} \mathrm{IBA} \text { (indol } \\
\text { butyric acid) }\end{array}$ & $\mathrm{MS}+2.0 \mathrm{mg} / \mathrm{L} \mathrm{kin}$ & $\mathrm{MS}+4.0 \mathrm{mg} / \mathrm{L} \mathrm{IBA}$ \\
\hline $\mathrm{T} 2$ & $\begin{array}{c}\text { MS+ 0.5 mg/L kin (kinten)+ 1mg/L NAA } \\
\text { (naphthalene acetic acid) }\end{array}$ & $\mathrm{MS}+2.0 \mathrm{mg} / \mathrm{L} \mathrm{kin}$ & $\mathrm{MS}+4.0 \mathrm{mg} / \mathrm{L} \mathrm{IBA}$ \\
\hline T3 & $\begin{array}{l}\mathrm{MS}+2.0 \mathrm{mg} / \mathrm{L} \text { kin }(\text { kinten})+1 \mathrm{mg} / \mathrm{L} 2,4-\mathrm{D} \\
(2,4-\mathrm{Di} \text { chloro phenoxy acetic acid })\end{array}$ & $\mathrm{MS}+2.0 \mathrm{mg} / \mathrm{L} \mathrm{kin}$ & $\mathrm{MS}+4.0 \mathrm{mg} / \mathrm{L} \mathrm{IBA}$ \\
\hline $\mathrm{T} 4$ & $\mathrm{MS}+1.0 \mathrm{mg} / \mathrm{L} \mathrm{kin}+2.0 \mathrm{mg} / \mathrm{L} 2,4-\mathrm{D}$ & $\mathrm{MS}+2.0 \mathrm{mg} / \mathrm{L}$ kin & $\mathrm{MS}+4.0 \mathrm{mg} / \mathrm{L} \mathrm{IBA}$ \\
\hline $\mathrm{T} 5$ & $\mathrm{MS}+2.0 \mathrm{mg} / \mathrm{L} \mathrm{kin}+2.0 \mathrm{mg} / \mathrm{L} 2,4-\mathrm{D}$ & $\mathrm{MS}+2.0 \mathrm{mg} / \mathrm{L} \mathrm{kin}$ & $\mathrm{MS}+4.0 \mathrm{mg} / \mathrm{L} \mathrm{IBA}$ \\
\hline T6 & $\begin{array}{c}\text { MS- sharkol+ } 0.5 \mathrm{mg} / \mathrm{L} \mathrm{BA}(\text { Benzyl adenine })+ \\
1.0 \mathrm{mg} / \mathrm{L} 2,4-\mathrm{D}\end{array}$ & $\mathrm{MS}+2.0 \mathrm{mg} / \mathrm{L} \mathrm{kin}$ & $\mathrm{MS}+4.0 \mathrm{mg} / \mathrm{L} \mathrm{IBA}$ \\
\hline $\mathrm{T} 7$ & $\begin{array}{c}\text { MS- sharkol+ } 1.0 \mathrm{mg} / \mathrm{L} \mathrm{BA}+0.25 \mathrm{mg} / \mathrm{LGA} \\
\text { (Gebrelic acid) }\end{array}$ & $\mathrm{MS}+2.0 \mathrm{mg} / \mathrm{L} \mathrm{kin}$ & $\mathrm{MS}+4.0 \mathrm{mg} / \mathrm{L} \mathrm{IBA}$ \\
\hline
\end{tabular}

\section{Plant Expression Vector}

The plasmid pAB6 (kindly provided by Dr. Bassem Abd Elgwad, Agricultural Genetic Engineering Research Institute) has been used for the transformation of Hyoscyamus muticus $\mathrm{L}$ callus. Plasmid map of transformation vector pAB6 is shown in Figure 1. The plasmid contains the Gus gene (with $1^{\text {st }}$ exon $\&$ intron) and terminated by Nos gene 3' non-translated region. It also contained Bar gene (controlled by $35 \mathrm{~S}$ promoter and Nos terminator) as a selective marker. The bar gene encodes phosphinothricin acetyl transferase (PAT) enzyme that inactivates the active ingredient phosphinothricin, of the bialaphos herbicide.

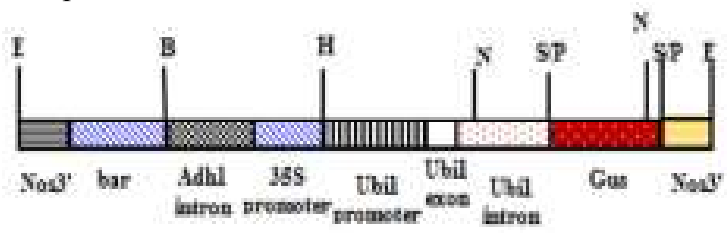

Figure 1. Plasmid map of the transformation vector pAB6.

Transformation was done by a biolistic particle acceleration device (PDS 1000/He, Bio-Rad). For microprojectile bombardment, plasmid DNA $\left(1 \mu \mathrm{g} \mu \mathrm{L}^{-1}\right)$ was precipitated onto gold particles $(0.7 \mu \mathrm{m}$ in diameter $)$ following the procedure described in the Bio-Rad instruction Manual. Henbane callus plates were bombarded twice at a pressure of 1300 and 1800 psi with $10 \mu \mathrm{L}$ of particle suspension mixture per bombardment.

Transformation experiments were performed on friable callus only exposed to an osmotic treatment of sorbitol (45.4 $\left.\mathrm{gL}^{-1}\right)$ of and mannitol $45.4 \mathrm{gL}^{-1}$ for $4 \mathrm{~h}$ before and $16 \mathrm{~h}$ after bombardment(Kikkert et al., 2005).

Selection and recovery of transformed calli

Bombarded callus was incubated on the best selected callus induction medium for one week after bombardment. The recovery period after bombardment allows the bombarded cells to recover from mechanical damage caused by accelerated gold particles. Also, this period gives the transformed cells enough time to begin the expression of introduced selectable marker genes which allows reliable selection (Weeks et al., 1993). Then, transformed calli were transferred for 2 weeks to same medium supplied with bialaphos $\left(1.0 \mathrm{mg} \mathrm{L}^{-1}\right)$ then to fresh selective bialaphos medium $\left(2 \mathrm{mg} \mathrm{L}^{-1}\right)$, with continued sub-culturing every 2 weeks; with cultures being in a dark growth chamber at $28^{\circ} \mathrm{C}$

Bialaphos-resistant calli having uniform growth were taken to regeneration bialaphos $\left(3 \mathrm{mg} \mathrm{L}^{-1}\right)$ medium. Somatic embryogenic calli developed within 2 to 4 weeks into green shoots were considered putative transformants and transferred to a shooting media. Plantlets were transferred to a $1 \mathrm{mgL}^{-1}$ bialaphos rooting medium the developed putatively transformed were transferred into Hoagland solution for 4 to 6 days, then transferred to soil in growth chambers (Cem et.al,2003)

\section{Evaluation of transformed plants}

\section{Herbicide testing}

PAT activity was done through indirect means, by assaying the resistance of transformed plants to the herbicide (product of Hoechst, Germany) containing 200 $\mathrm{gL}^{-1}$ glufosinateammoniuim. The basta was painted on leaves of the putatively transformed plants. Application was done on 5 to $10 \mathrm{~cm}$ leaf sectors near the tip of the youngest fully-extended leaf at the four-and eight-leaf stage with a $1 \%$ solution of the herbicide containing $0.1 \%$ (v/v) Tween 20. (Roger and Bendich ,1985)

\section{Molecular Analysis}

\section{Genomic DNA extraction}

Isolation of genomic DNA from leaf tissues of each putatively transformed plant was done on untransformed and control plants using a modified CTAB method (Rogers and Bendich, 1985).

\section{Polymerase chain reaction analysis}

Detecting the bar and HVAI genes was done by PCR on 2 primer sets. Specific primer sequences bar genes of Nos-Gus and 35S- are shown in Table 2.

Table 2. Sequence of specific primers for the Nos-Gus and 35S- Bar genes.

\begin{tabular}{|c|c|c|}
\hline Gene code & Forward primer & Reverse primer \\
\hline Nos- Gus gene & $\begin{array}{l}\text { 5'- GGT GAT CTA ACC ATG GCC TCC AAC CAG AAC } \\
\text { CAG GGG -3' }\end{array}$ & $\begin{array}{l}\text { 5'- GGC ATA TCT ATT GAT TCC TGG } \\
\text { TGGTGGTGG TG -3' }\end{array}$ \\
\hline $35 \mathrm{~S}-$ Bar gene & 5'-TGG CAC CGA GGA GAC ATG CCG GC-3 & 5'-CGT GAG GTG GAG GCC \\
\hline
\end{tabular}

The PCR technique was done on $25 \mathrm{uL}$ reaction volume having the followings: - $25 \mathrm{ng}$ of genomic DNA, 25 pmol mL-1 primers, 200 umol of each of dATP,
dCTP,dGTP and DTTP,50 $\mu \mathrm{M} \mathrm{KCl,} 10 \mathrm{mM}$ Tris- $\mathrm{HCl}, 0.2$ $\mathrm{mM} \mathrm{MgCl} 2$ and one unit of Taq polymerase enzyme.

For the amplification, temperature profile of $94^{\circ} \mathrm{C}$ for $5 \mathrm{~min}$ for the initial denaturation cycle followed by 35 cycles 
of $1 \min 94{ }^{\circ} \mathrm{C}, 2 \min 60^{\circ} \mathrm{C} 2 \min 72^{\circ} \mathrm{C}$ and a terminal extension $10 \mathrm{~min}$ cycle $72{ }^{\circ} \mathrm{C}$ for the gus and bar genes. The PCR products were resolved by electrophoresis on $30 \mathrm{~g}$ agarose gel per liter (Dellaporta et al., 1983). Data were analyzed statistically (Gomez and Gomez, 1984)

\section{RESULTS AND DISCUSSION}

The results presented in Table 3 indicate that the highest callus induction frequency (22.69) was recorded by maintaining the leaf explants on callus induction medium T3. However, the lowest callus induction frequency (6.65) was shown by maintaining on medium $\mathrm{T} 7$.

All calli maintained on medium T3 showed more positive response in embryogenic calli formation frequency $(84.95 \%)$ in comparison with other media. These results reveal that components of medium T3 (specially the $2.0 \mathrm{mg}$ $\mathrm{L}^{1}$ kin $\left.+1 \mathrm{mg} \mathrm{L}^{-1} 2,4-\mathrm{D}\right)$ caused marked effects on the quality and quantity of embryogenic calli formation (Figure 2).

Transfer of the embryogenic calli obtained on callus induction media induced regeneration using media containing $2.0 \mathrm{mg} \mathrm{L}{ }^{1} \mathrm{kin}$. Green shoot formation was evident within two weeks. Data obtained in Table 3 and Figure 2 indicate that the highest shoot formation frequency was recorded by maintaining the calli on callus induction medium T3 (7.65 per explant).

On the other hand, the lowest shoot formation frequency ( 0.18 per explant) occurred by calli maintained on medium T7. This indicates an improvement of callus induction and maintenance of medium T3 caused enhancement of shoot formation ability of Hyoscyamus muticus L genotype, as well as, production of high root yield after transfer onto rooting medium contained $4.0 \mathrm{mg} \mathrm{IBA} \mathrm{L}^{-1}$.

Table 3. Callus parameters and embryogenesis frequency of Hyoscyamus muticus $L$ maintained on different media

\begin{tabular}{lcccccc}
\hline $\begin{array}{l}\text { Media } \\
\text { callus } \\
\text { induction }\end{array}$ & $\begin{array}{c}\text { Callus } \\
\text { uniformity }\end{array}$ & $\begin{array}{c}\text { Explant weight } \\
\text { before culturing } \\
\text { g/explant }\end{array}$ & $\begin{array}{c}\text { callus weight } \\
\text { after culturing } \\
\text { g/explant }\end{array}$ & $\begin{array}{c}\text { Growth } \\
\text { rate } \\
\text { g/explant }\end{array}$ & $\begin{array}{c}\text { Embryogenesis } \\
\text { frequency } \\
\text { \% }\end{array}$ & $\begin{array}{c}\text { Mean number } \\
\text { of } \\
\text { shoots/ explants }\end{array}$ \\
\hline T1 & Compact & 1.87 & 12.32 & 10.45 & 16.65 & 0.39 \\
T2 & Compact & 2.53 & 11.41 & 8.88 & 18.03 & 0.47 \\
T3 & Friable & 3.79 & 26.48 & 22.69 & 84.95 & 7.65 \\
T4 & Friable & 2.03 & 15.45 & 13.42 & 39.16 & 2.11 \\
T5 & Friable & 2.83 & 11.73 & 8.9 & 36.89 & 1.59 \\
T6 & Watery & 2.11 & 9.98 & 7.87 & 4.12 & 0.21 \\
T7 & Watery & 2.67 & 6.65 & 3.98 & 2.34 & 0.18 \\
\hline LSD 5\% & & 2.29 & 1.48 & 1.45 & 1.24 & 0.86 \\
\hline
\end{tabular}
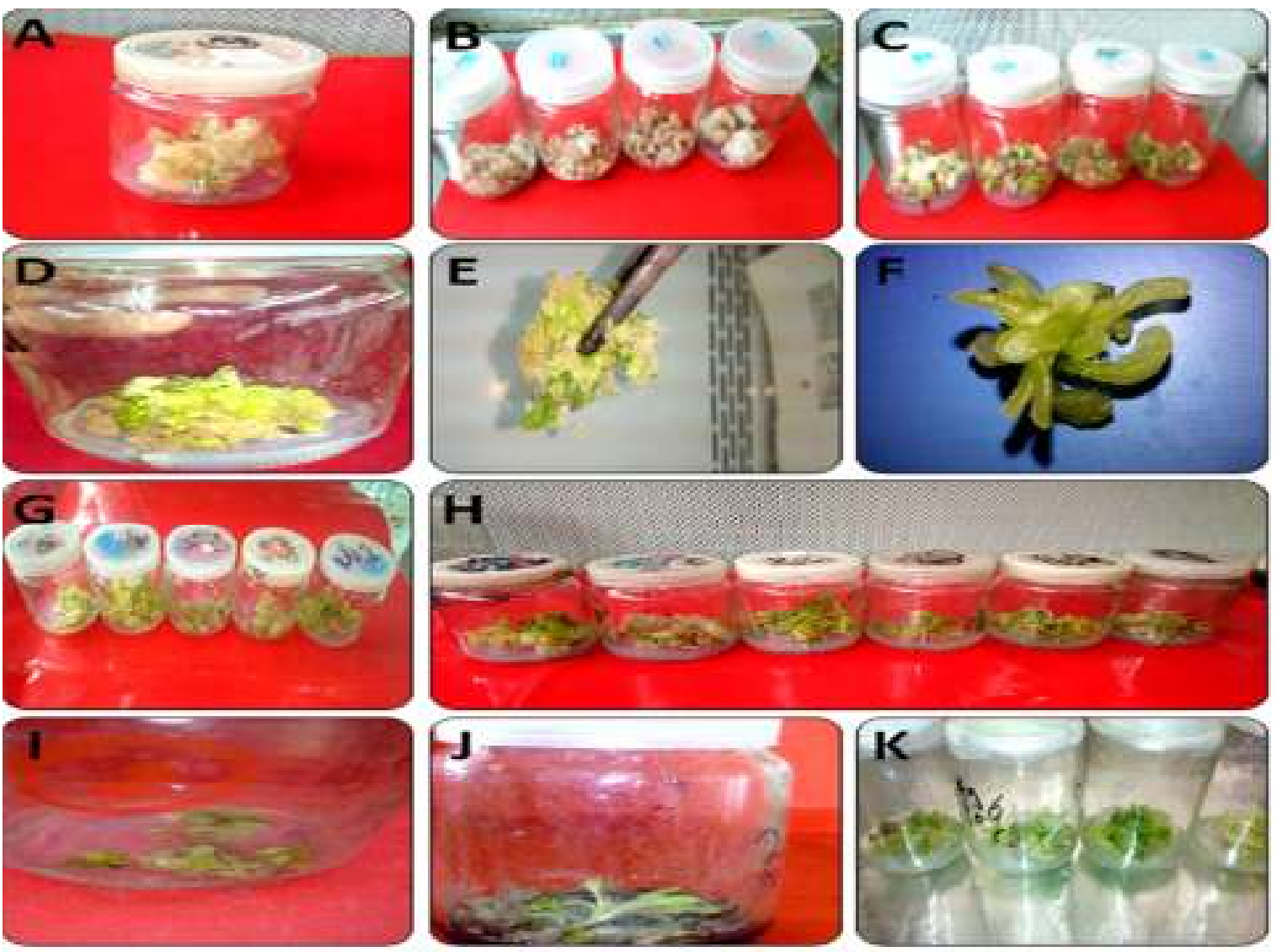

Figure 2. Hyoscyamus muticus $L$ regeneration of callus induction on medium T3 (A, B and C), somatic embryogenesis (D, E and F) and shoots proliferation ( $G$ and $H)$ plantlets on regeneration medium.

Note: (I) watery calli on T6 medium. (J) watery calli on $\mathrm{T} 7$ medium. (K) compact calli on $\mathrm{T} 2$ medium. 
Although, more embryogenic calli ranging between 2.34 (T7) and $84.95 \%$ (T3) were formed by Hyoscyamus muticus $\mathrm{L}$ and maintained on different media, most of these calli failed to form healthy root system on the regeneration medium, while calli maintained on T3 medium were able to produce very efficient rooting systems, as shown in Figure 3.

Therefore, the $2.0 \mathrm{mg} \mathrm{L}^{-1} \mathrm{kin}+1 \mathrm{mg} \mathrm{L}^{-1} 2,4-\mathrm{D}$ promoted fast differentiation that led to increased number of shoots, and more regeneration suitable for rooting shoots than other media. These results indicate that the presence of such components in callus induction medium is recommended for initiating friable embryogenic callus. These results agree with those of Abd-Elmaksood et al., (2016), who proposed MS medium supplemented with 1.0 $\mathrm{mg} \mathrm{L}^{-1} \mathrm{KN}$ as the most promising treatment for establishment and continuous proliferation of $H$. muticus L. explants during successive subcultures. Ali et al., (2010) studied media types, strengths, components and combinations of auxin and cytokinin (NAA and BA) and found that the light and inoculum density increased total alkaloid which accumulated in suspension cultures of Hyoscyamus muticus L. The same pattern was reported by Bhardwaj et al. (2018), who observed high percentage of callus induction in medium containing 10 to $15 \mu \mathrm{M}$ NAA from Rhodiolaimbricata genotypes with highest percentage of shoot given by leaf derived callus medium of $5 \mu \mathrm{M}$ NAA and $2.5 \mu \mathrm{M}$ BAP as well as $1.0 \mu \mathrm{M}$ NAA , $5 \mu \mathrm{M}$ BAP, 5 $\mu \mathrm{M}(38.88 \%$ and $37.49 \%)$; rooting of regenerated shoots as effective when a lower concentration of NAA $(0.5 \mu \mathrm{M})$ was used alone. However, a maximum number of roots (22.0) and higher length $(0.6 \mathrm{~cm})$ was observed.

On the other hand, Ngetich et al. (2018) used MS medium components of $\alpha$-naphthaleneacetic acid (NAA), 2,4- dichlorophenoxy acetic acid (2,4-D), benzyl aminopurine (BAP) and kinetin for callus induction and somatic embryogenesis in millets for shoot and root inductions
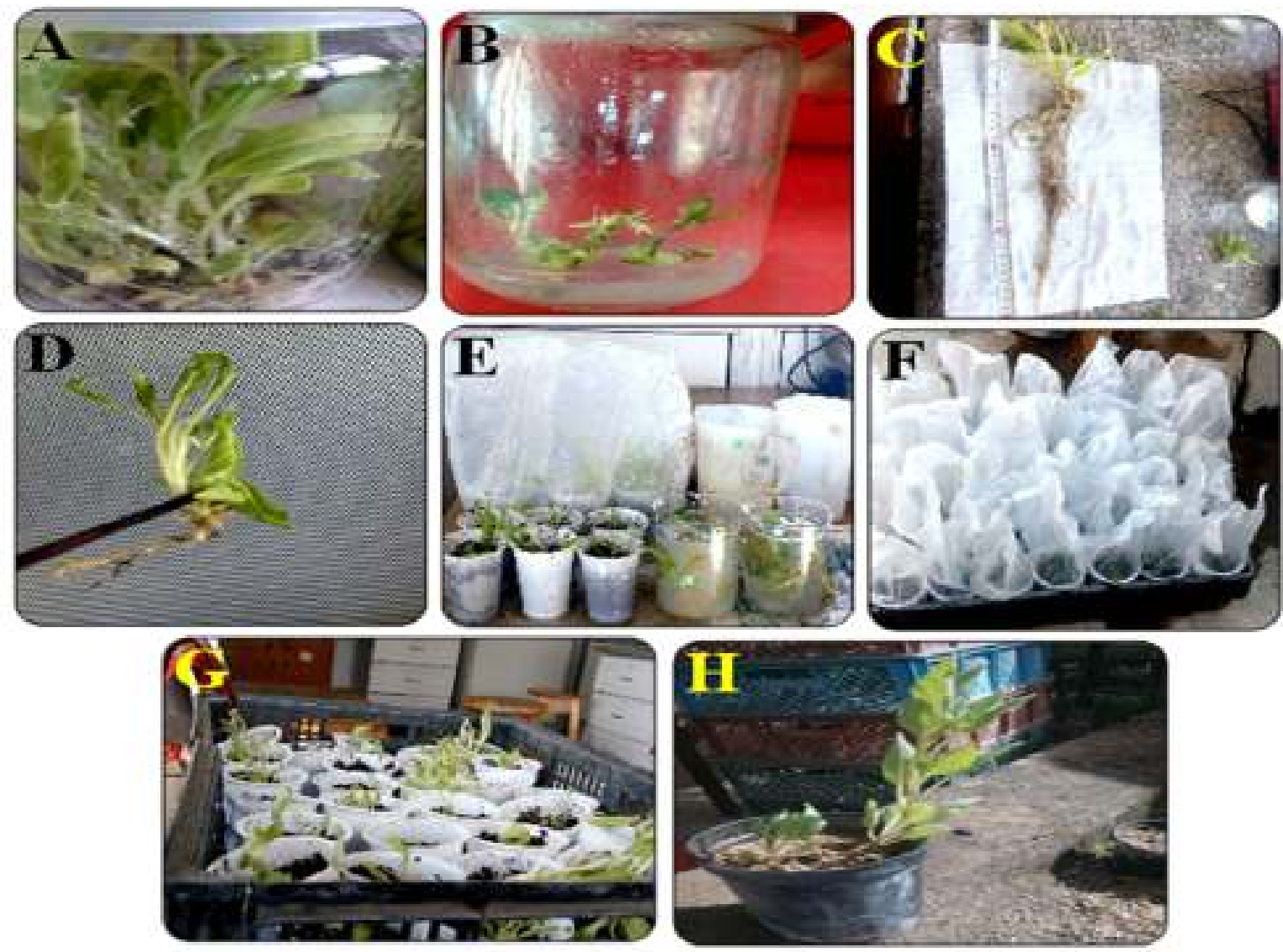

Figure 3. Regenerated plantlets (A, B) on rooting medium T3 and T7. Plant root profile (C, D), regenerated Hyoscyamus muticus $L$ plants in Hoagland solution (E, F and $G$ ) and fertile regenerated plants $(\mathrm{H})$ appeared, respectively.

\section{Hyoscyamus muticus $\mathrm{L}$ transformation}

Transformed henbane plants were achieved by particle bombardment using plasmid pAB-6 harboring the gus and bar genes. Transformation experiments were performed on the most effective calli of medium T3 achieved in the regeneration protocol. The putatively transformed calli were selected on the same medium supplemented with bialaphos as a selective agent (Figure 4).
Data presented in Table 4 show three transformation experiments performed using 300 callus pieces, which produced 256 embryogenic calli with a high average number of embryogenic calli (85.3\%). These results reflect the average regeneration frequency of plant genotype which produced $27.3 \%$ of shoots on selective medium. 
Table 4. The average number of embryogenic calli formed by Hyoscyamus muticus $\mathrm{L}$ on selective medium and their regeneration efficiency

\begin{tabular}{lccccc}
\hline $\begin{array}{l}\text { No. } \\
\text { of } \\
\text { experiment }\end{array}$ & $\begin{array}{c}\text { No. of } \\
\text { treated } \\
\text { calli }\end{array}$ & $\begin{array}{c}\text { Average No. of } \\
\text { embryogenic calli } \\
\text { on free media }\end{array}$ & $\begin{array}{c}\text { Average No. of } \\
\text { survival calli on } \\
\text { selective media }\end{array}$ & $\begin{array}{c}\text { Average No. of } \\
\text { shoots on selective } \\
\text { media }\end{array}$ & $\begin{array}{c}\text { Regeneration } \\
\text { Frequency } \\
\text { \%o }\end{array}$ \\
\hline 1 & 100 & 89 & 56 & 31 & 31 \\
2 & 100 & 81 & 44 & 24 & 27 \\
3 & 100 & 86 & 51 & 82 & 27 \\
\hline Total & 300 & 256 & 151 & 27.3 & 27 \\
Mean & 100 & 85.3 & 50.3 & 27 \\
\hline
\end{tabular}
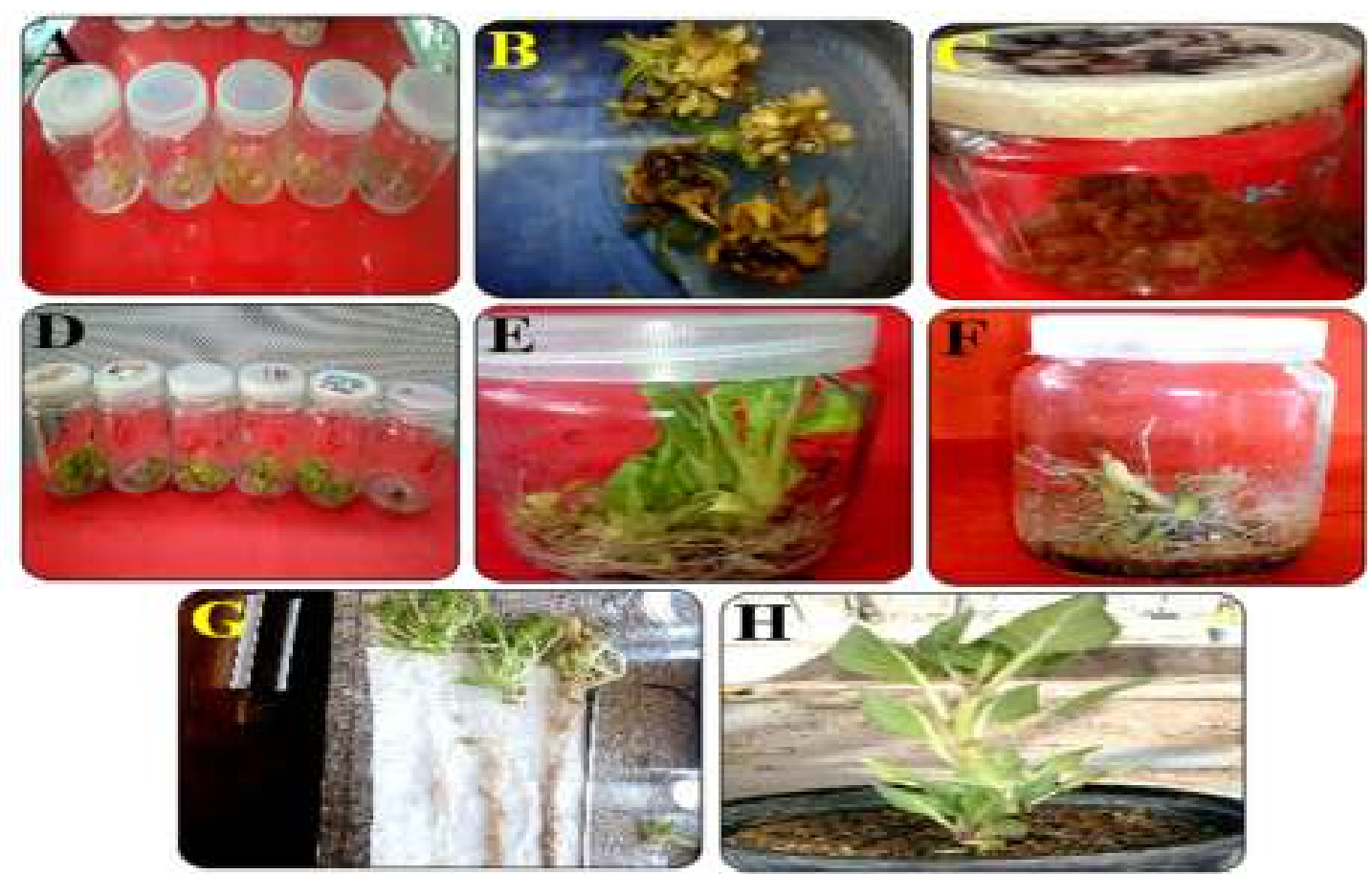

Figure 4. Transformed Calli $(\mathrm{A}, \mathrm{B})$ on $\mathrm{T3}$ medium containing $1.5 \mathrm{mgL}^{-1}$ bialaphos and $3 \mathrm{mgL}^{-1}$ bialaphos, respectively. Non-transformed calli $(C)$, regenerated transformed plantlets $(D, E)$ on rooting medium containing $1.0 \mathrm{mgL}^{-1}$ bialaphos, non-transformed plantlets $(F)$, transformed plant root profile $(G)$ and regenerated transformed plants $(\mathrm{H})$ appeared, respectively.

Success of transformation was correlated with the integration, level of expression and functionality of transgenes in transgenic plants (Zarata and Verpoorte ,2007). The PCR confirmed the presence of both gus and bar genes in the DNA extracted from transgenic plants as shown in Table 5 and Figure 5.

Eighty two putative regenerated plants recovered from the selection step were obtained. A number of 11 from 82 plants succeeded in producing a positive result

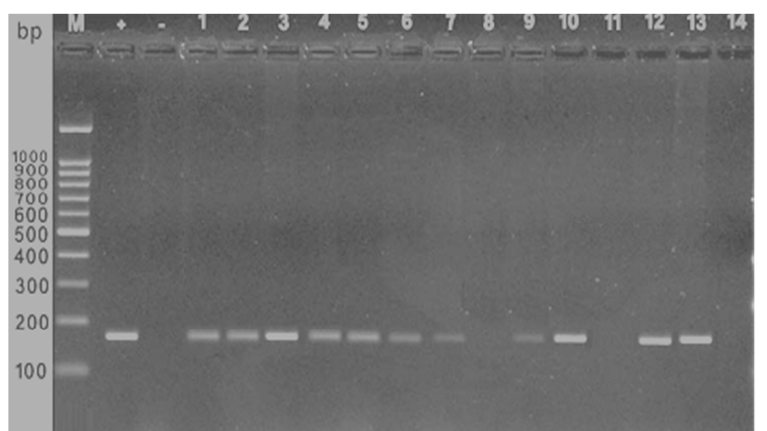

with PCR for the gus and bar genes with transformation efficiency of $13.4 \%$. Such efficiency is greater than the $2.2 \%$ in maize obtained by Assem et al. (2008).

Or the 1.5 to $4.0 \%$ obtained by Altpeteret al. (2005) or $1.3 \%$ in paspalumnotatumflugge obtained by Agharkar et al. (2007) or the $1.6 \%$ in Eleusinecoracana obtained by Jagga-Chugh et al. (2012). Song et al. (2006) obtained transformation efficiency of $13 \%$ was on Populus trichocarpa.

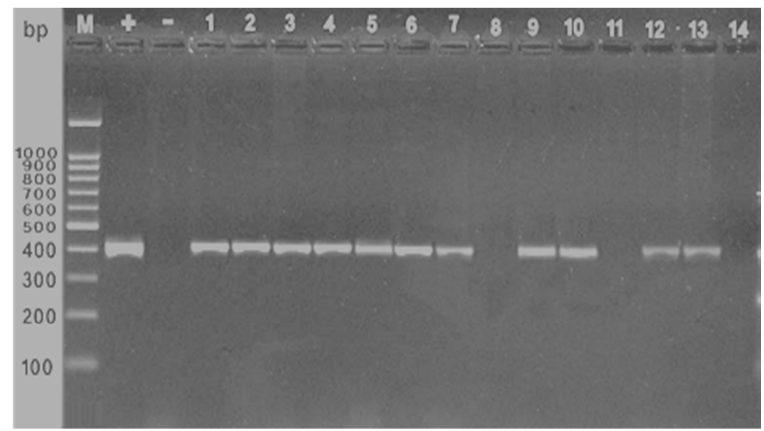

Figure 5. PCR amplified DNA using Gus gene specific primers (A) and the Bar gene primers (B).

Note: positive control from pAB6 plasmid $(+)$, untransformed plant $(-)$, putatively transformed Hyoscyamus muticus L plants (1-14) and (M) 100bp ladder marker. 
Table 5. Molecular analysis and alkaloid content of the transformed plants.

\begin{tabular}{|c|c|c|c|c|c|c|}
\hline \multirow{2}{*}{$\begin{array}{l}\text { No. of } \\
\text { plants }\end{array}$} & \multicolumn{2}{|c|}{$\begin{array}{l}\text { PCR } \\
\text { Assay }\end{array}$} & \multirow{2}{*}{$\begin{array}{c}\text { Leaf } \\
\text { painting }\end{array}$} & \multicolumn{3}{|c|}{$\begin{array}{l}\text { Total alkaloids } \\
\text { mg/g dry weight }\end{array}$} \\
\hline & $\begin{array}{c}\text { Gus } \\
\text { gene }\end{array}$ & $\begin{array}{l}\text { Bar } \\
\text { gene }\end{array}$ & & Control & $\begin{array}{c}\text { Regenerated } \\
\text { plants }\end{array}$ & $\begin{array}{l}\text { Transformed } \\
\text { plants }\end{array}$ \\
\hline 1 & + & + & ++ & 2.95 & 5.45 & 5.94 \\
\hline 2 & + & + & ++ & 2.95 & 5.79 & 5.59 \\
\hline 3 & + & + & +++ & 2.95 & 4.97 & 7.1 \\
\hline 4 & + & + & ++ & 2.95 & 5.88 & 6.11 \\
\hline 5 & + & + & ++ & 2.95 & 5.11 & 6.45 \\
\hline 6 & + & + & ++ & 2.95 & 5.98 & 6.43 \\
\hline 7 & + & + & + & 2.95 & 6.01 & 5.06 \\
\hline 8 & - & - & - & 2.95 & 4.97 & 4.91 \\
\hline 9 & + & + & + & 2.95 & 4.93 & 5.94 \\
\hline 10 & + & + & +++ & 2.95 & 5.91 & 6.88 \\
\hline 11 & - & - & - & 2.95 & 5.67 & 4.88 \\
\hline 12 & + & + & +++ & 2.95 & 5.33 & 7.39 \\
\hline 13 & + & + & +++ & 2.95 & 4.18 & 7.31 \\
\hline 14 & - & - & - & 2.95 & 4.94 & 4.67 \\
\hline Mean & & & & 2.95 & 5.36 & 6.05 \\
\hline LSD5\% & & & & 0.35 & 0.35 & 0.35 \\
\hline
\end{tabular}

Painting plant leaves with herbicide basta was effective in evaluating the production of transformed plants harboring the bar gene, (Yadava et al., 2017). Herbicide resistance of two transformed tested by such technique enabled plant resistance after one week of painting. Transformed leaves resisted the herbicide and maintained their green color, while the non-transformed leaves became yellow to white following 5 days after painting (Figure 6).

Results demonstrate the positive results for total alkaloid content maintained on tissue culture media particularly the $\mathrm{T} 3$ medium $\left(5.36 \mathrm{mg} \mathrm{g}^{-1}\right.$ dry weight in comparison with field plants which recorded mean value of $2.95 \mathrm{mgg}^{1}$ dry weight. On the other hand, there was greater effect of transformation on the transformed plants which increased the content of hyoscyamine alkaloid (6.05 $\mathrm{mg} \mathrm{g}^{-1}$ dry weight) more than the untreated plants.

Transformation studies on plants using particle bombardment-mediated transformation carried out by Clapham et al. (2003) on Norway spruce (Piceaabies) and Malabadi and Nataraja, (2007) on Himalayan blue pine (Pinus wallichiana ) are in agreement with results in the current study.
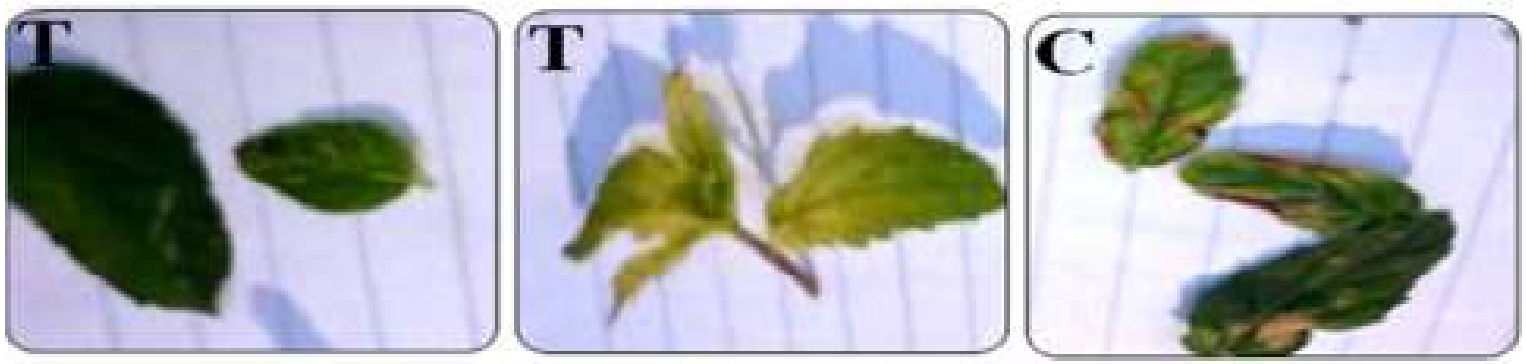

Figure 6. Leaves of transformed plant $(\mathrm{T})$ and non-transformed control plant $(\mathrm{C})$ painted with herbicide Basta solution.

In conclusion, the method described in the current study seems promising for an efficient in vitro regeneration of H. muticus L. (Egyptian henbane) using KN and 2,4-D. This could be useful for large scale production and provides a possible technique for plant conservation system to obtain a high-yielding trans-formant maintaining their diversity.

Transformed plants appeared over expression of Gus and Bar genes. The metabolite detection showed that alkaloids content (hyoscyamine) underwent marked increase.

Transformation was effective increasing gene products and can be used for characterizing the function of genes. Tissue culture and genetic transformation could be used as a factory to produce many important medical products on a large scale, as well as, to study gene expression. Hence, it is a suitable time to replace tobacco with Egyptian Henbane for its medicinal importance.

\section{REFERENCES}

Abd El-Motaleb, M., Abd El-Hameid A.R., Elnaggar H.M.H. and Abdel-Hady M.S. (2015) Callus induction and regeneration of Stevia rebaudiana Bertoni. Int. J. ChemTech Res. 8(6): 868-877.

Abd Elmaksood, W. M.; Ebad, F. A. and Hussein, B.A. (2016). In vitro Propagation of the Endangered Medicinal Plant Hyoscyamusmuticus L. (Egyptian Henbane). J. Appl. Environ. Biol. Sci., 6(4)25-34.
Agharkar, M.; Lomba, P.;Altepter, F.; Zhang,H.; Kenwwort,K. and Lange,T.(2007). Stable expression of AtGA2ox1 in alow input turf grass (paspalumnotatumflugge) reduces bioactive gibberellins levels and improves turf quality under felled conditions. plant biotechnology 5: 791-801

Ahmad, M. M., Ali, A., Siddiqui, S., Kamaluddin, and Abdin, M. Z. (2017). Methods in transgenic technology in Plant Biotechnology: Principles and Applications, eds M. Z. Abdin, U. Kiran, Kamaluddin, and A. Ali (Singapore: Springer), 93-115.

Altpeter, F., Baisakh, N., Beachy, R., Bock, R., Capell, T., Christou, P. (2005). Particle bombardment and the genetic enhancement of crops: myths and realities. Mol. Breed. 15, 305-327.

Ali, U. I.; El-Shabrawi, H. M. and Hanafy, M.(2010).Impact of Culture Conditions on Alkaloid Production from Undifferentiated Cell Suspension Cultures of Egyptian Henbane. Australian Journal of Basic and Applied Sciences, 4(10): 4717-4725.

Assem, S.K., E.H.A. Hussein and T.A. El-Akkad (2008). Genetic transformation of Egyptian maize lines using the late embryogenesis abundant protein gene, HVA1, from barley. Arab J. Biotech. 11(1): 59-70.

Bekheet, S.A.; Taha, H.S. and Gabr, A.M.M. (2013). Protocol for in vitro morphogenesis and hairy root cultures of Milk thistle (Silybummarianum L. Gaertn). Journal of Applied Sciences Research, 9(1):860-866. 
Berlin, J.(1988). Formations of secondary metabolites in cultured plant cells and its impact on pharmacy. In Bajaj YPS (Eds.) Biotechnology in Agriculture and Forestry, 4: 37-59.

Bhardwaj, A.K.; Naryal,A.; Bhardwa,P.; Warghat, A.R.; Arora,B.; Dhiman,A.; Saxena,S.; Pati,P.K. and Chaurasia, O.(2018). High Efficiency in vitro Plant Regeneration and Secondary Metabolite Quantification from Leaf Explants of Rhodiola imbricate. Pharmacogn J.; 10(3):470-475.

Cem, E. O., Takahashi, M., Sakamoto, A., and Morikawa, H. (2003). Development of regeneration and transformation systems for Rhaphiolepisumbellata $\mathrm{L}$. Plants using particle bombardment. Plant Biotechnol. 20, 145-152.

Clapham, D. H., Häggman, H., Elfstrand, M., Aronen, T., and Arnold, S. V. (2003). Transformation of Norway Spruce (Piceaabies) by Particle Bombardment. Berlin: Springer. doi: 10. 978-988

Dellaporta, S.L., J. Wood and J.B. Hicks (1983): A plant DNA mini preparation. Version III. Plant Mol. biol., 1:19-21.

Ganga, B.R., Umamaheswara P.R., Sambasiva E.R., Mallikarjuna T.R. and Praneeth V.S. (2011). Studies on phyto chemical constituents, quantification of total phenol, alkaloid content and In-vitro antioxidant activity of Cocciniacordifolia. Int. J. Pharm. Life Sci. 2:1177-1182.

Gomez, K.A. and A.A. Gomez (1984). Statistical procedures for agricultural research $2^{\text {nd }}$ edition, John wiley, sons, New York.

Hai-Hang, L. (2012). Editorial Message to the Journal of Medicinal \& Aromatic Plants. Med Aromat Plants, 1(3): 2167-2172.

Jagga-Chugh, S., Kachhwaha, S., Sharma, M., KothariChajer, A., and Kothari, S. L. (2012). Optimization of factors influencing microprojectile bombardmentmediated genetic transformation of seed-derived callus and regeneration of transgenic plants in Eleusinecoracana (L.) Gaertn. Plant Cell Tissue Organ Cult. 109, 401-410.

Johnson, C.M.; Stout, P.R.; Broyer, R.C. and Carlton, A.B. (1957). Comparative chlorine requirements of different plant species. Plan and soil 8:337-353.
Kikkert, J. R., Vidal, J. R., and Reisch, B. I. (2005). Stable transformation of plant cells by particle bombardment/biolistics. Methods Mol. Biol. 286, 61-78.

Malabadi, R. B., and Nataraja, K. (2007). Stable transformation and recovery of transgenic plants by particle bombardment in Pinus wallichiana A.B. Jacks (Himalayan Blue Pine). Biotechnology 6, 105111.

Murashige, T. and F. Skoog, (1962). A revised medium for rapid growth and bioassays with tobacco cellcultures. Physiologia Plantarum, 15: 473-479.

Ngetich, Al.; Mweu, C.; Ngugi, Mathew, A.; Mukami, H. O. and Mbinda, W.(2018). Efficient plant regeneration protocol for finger millet [Eleusinecoracana (L.) Gaertn.] viasomatic embryogenesis. African Journal of Biotechnology 17(21), pp. 660-667.

Purkayastha, J., Sugla, T., Paul, A., Solleti, S. K., Mazumdar, P. andBasu, A. (2010). Efficient in vitro plant regeneration from shoot apices and gene transfer by particle bombardment in Jatropha curcas. Biol. Plant. 54, 13-20.

Rogers, S.O. and Bendich, A.J. (1985). Extraction of DNA from milligram amount of fresh herbarium, and mummified plant tissue. Plant Mol.Biol. 5:69-76.

Song, J., Lu, S., Chen, Z. Z., Lourenco, R., and Chiang, V. L. (2006). Genetic transformation of Populustrichocarpa genotype Nisqually-1: a functional genomic tool for woody plants. Plant Cell Physiol. 47, 1582-1589.

Weeks, J.T.; Anderson, O.D. and Blechl, A.E. (1993) .Rapid production of multiple independent lines of fertile transgenic wheat (Triticum aestivum). Plant Physiol. 102:1077-1084.

WHO (1999): Monographs on selected medicinal plants, World Health Organization; Vol. 1. Geneva.

Yadava, P., Abhishek, A., Singh, R., Singh, I., Kaul, T., attanayak, A., et al. (2017). Advances in maize transformation technologies and development of transgenic maize. Front. Plant Sci. 7:1949. -1959

Zárate, R., and Verpoorte, R. (2007). Strategies for the genetic modification of the medicinal plant Catharanthus roseus (L.) G. Don. Phytochem. Rev. 6, 475-491.

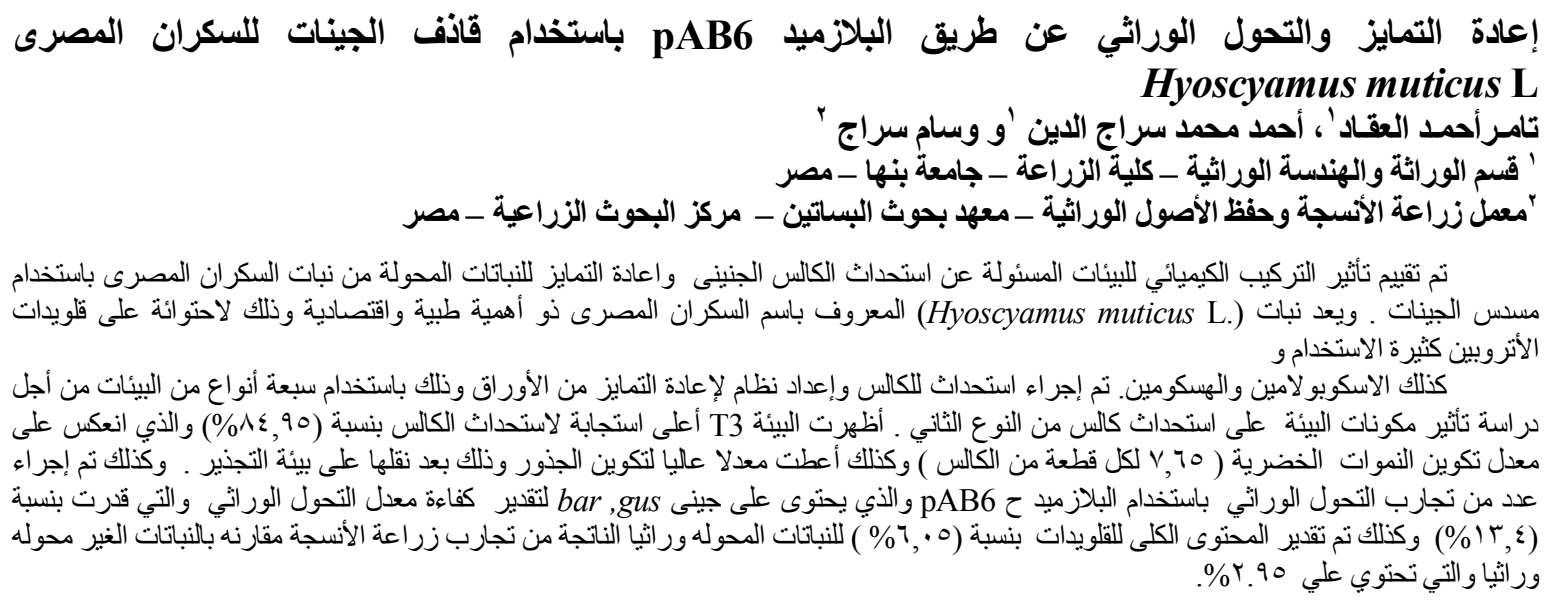

